\title{
Coleoptile length and plant height of modern tall and semi-dwarf European winter wheat varieties
}

\author{
Žilvinas Liatukas*, Vytautas Ruzgas \\ Institute of Agriculture, Lithuanian Research Centre for Agriculture and Forestry, Instituto av. 1,58344 Akademija, Kèdainiai district, Lithuania
}

\begin{abstract}
A total of 124 recent winter wheat accessions of European origin were screened for coleoptile length and plant height. Most of the accessions (74.2\%) possessed a coleoptile length ranging between 5.00 and $7.00 \mathrm{~cm}$. The German varieties Ebi, Pegassos, Flair without Rht genes had a coleoptile length of 9.08, 9.43, $9.56 \mathrm{~cm}$ and a plant height of 97,95 and $98 \mathrm{~cm}$, respectively. The Serbian variety Pobeda possessing Rht8 had a coleoptile length of $9.14 \mathrm{~cm}$ and a plant height of $71 \mathrm{~cm}$. The varieties possessing $R h t-B 1 b, R h t-D 1 b$ had a significantly shorter mean coleoptile length $(5.45 \mathrm{~cm})$ and mean plant height $(84.5 \mathrm{~cm})$ than the varieties without $R h t$ genes $(7.41$ and $99.6 \mathrm{~cm})$. The correlation between coleoptile length and plant height was medium $(\mathrm{r}=0.613, p$ $<0.01)$ when the calculation excluded the varieties from Central and Southern Europe. The similar plant height, but not coleoptile length of the varieties possessing different dwarfing factors enables development of novel varieties with desirable height and coleoptile length from the European winter wheat germplasm.
\end{abstract}

Keywords: Triticum aestivum, coleoptile length, plant height, $R$ ht genes

\section{Introduction}

Coleoptile length is an important winter wheat varietal trait as it determines the maximum depth at which seeds can be sown. It is a primary trait for varieties grown in dry areas where seeds are placed deeper than usual to reach wet soil. Soil conditions are so specific that only genotypes possessing very long coleoptiles can be grown, even they are agronomically out-dated. Most of the landraces grown in such areas possess a coleoptile length of about $10 \mathrm{~cm}[1,2]$. Currently, semi-dwarf varieties prevail in the world due to intensive use of dwarfing genes Rht-D1 and Rht-B1 which shorten both plant height and coleoptile length. Also, genes Rht-D1 and Rht-B1 are associated with increased winter wheat susceptibility to Fusarium head blight $[3,4]$. However, highly positive influence of $R h t-D 1$ and $R h t-B 1$ on growing technology and grain yield explains why these genes in combination with a complex of negative effects are so widespread. Less widespread gene $R h t 8$ also conditions wheat dwarfing but has no negative impact on coleoptile length $[2,5]$.

Winter wheat receives enough precipitation for shallow sowing and high yield in many parts of Europe. However, during

*Corresponding author. Email: liatukas@lzi.It

This is an Open Access digital version of the article distributed under the terms of the Creative Commons Attribution 3.0 License (creativecommons.org/licenses/ by/3.0/), which permits redistribution, commercial and non-commercial, provided that the article is properly cited. the past decade winter wheat establishment due to dryer seed bed was insufficient in some experimental plots across the Europe [6,7]. This problem could be solved by deeper sowing. Varieties are not screened under field conditions for deep sowing in Lithuania. Increasing use of non-plough tillage in Europe [8] also does not favor better seedling establishment under dry soil conditions. Recent unprecedented weather events in Europe [9] and the trends of climate change suggest greater variability and unpredictability of weather events influencing sustainable agriculture $[7,10]$. Some prognoses are very contradictory or even speculative. We can find various examples of changes in winter wheat breeding tasks in Europe over the last decades. Several decades ago winter wheat frost resistance was a mandatory trait for a variety in Northern and Western Europe. At present it has become a questionable trait due to the climate warming. In the near future, the development of new winter wheat type possessing long coleoptiles and adapted to wider range of environments can be a new challenge for European breeders.

At present, varieties possessing long coleoptiles have no exceptional advantage for European countries over a wide area. Althought such varieties can perform better in some situations. Longer coleoptiles improve stand establishment where stubble retention is practiced [11]. This trait for European varieties can become desirable, as soil non-plough techniques have become more widespread in Europe [8]. Seed treatment pesticides as well as other soil-applied pesticides can decrease coleoptile length, and the varieties with longer coleoptiles suffer less [12]. The similar relationship was found for coleoptile elongation dependence on temperature [13]. Longer coleoptiles can increase seedling emergence when small seeds are used [14]. Deeper sowing results in higher seed survival 
because it prevents damage done by animals [15]. Longer coleoptiles provide greater seedling early vigour, competition with weeds, crop establishment, more efficient soil water use, and better penetration through soil crust $[16,17]$. European varieties possessing genes $R h t-B 1 b$ and $R h t-D 1 b$ were characterized by reduced seed viability and lower early resource capture in combination with lower competitiveness with weeds [18]. Varieties possessing longer coleoptiles generally have faster, more even emergence and improved early vigour [11]. This trait is not essential for varieties grown under intensive pesticide input technologies. But it is a very important trait considerably improving weed competitiveness of winter wheat grown in organic conditions [19]. Conventional growers can get some benefits since more competitive varieties should require lower herbicide doses and/or less sophisticated herbicides.

Winter wheat germplasm possessing long coleoptiles is determined and available $[1,2,20]$. However, involvement of exotic germplasm with a complex of undesirable agronomic traits can impede breeding. Many Southern and Central European varieties possess $R h t 8$ alone or in combinations with $R h t-D 1$ or Rht-B1 [5,21]. Probably, some of them possess long coleoptiles. As a result, this region could apply deeper sowing of the selected varieties with long coleoptiles. The varieties possessing Rht8 also possess photoperiod insensitivity gene $P p d$. This germplasm should be investigated more comprehensively for frost resistance to be used for breeding purposes in Northern and Western European countries [18]. Moreover, such early flowering and ripening germplasm is hardly suitable for the above mentioned region due to lower yielding capacity [3].

The best way to tackle this problem is to select regionally adapted germplasm as it does not complicate breeding due to introduction of undesirable traits. Most of the recent European semi-dwarf winter wheat varieties possess genes $R h t$ $D 1$ and $R h t-B 1$ and possibly short coleoptiles $[18,22]$. On the other hand, there are some semi-dwarf varieties without $R h t$ genes [3]. This shows a probability to find varieties possessing at least medium long coleoptiles $(7-9 \mathrm{~cm})$. Also, older tall European cultivars could be used as one of the germplasm groups.

The objective of this research was to investigate the coleoptile length and plant height of some modern tall and semi-dwarf European winter wheat varieties and breeding lines, originated from Nordic, Western, Central and Southern regions.

\section{Material and methods}

\section{Plant material and evaluation of plant height}

In total 124 winter wheat modern varieties and breeding lines from 10 European countries covering various climatic conditions [Croatia (HR), Denmark (DK), Estonia (EE), France (FR), Germany (DE), Hungary (HU), Lithuania (LT), Serbia (RS), Sweden (SE), United Kingdom (UK)] were screened, (Fig. 1, Tab. 1).

The study was done at the Lithuanian Institute of Agriculture $\left(55^{\circ} 23^{\prime} \mathrm{N}, 23^{\circ} 51^{\prime} \mathrm{E}\right)$ situated in the center of Lithuania during 2005/2006 and 2006/2007 growing seasons under the same growing technology. The accessions tested were sown at a rate of 4.5 million viable, untreated seeds per ha at a depth of about $4 \mathrm{~cm}$, with a $15 \mathrm{~cm}$ row spacing. The crop was planted in the first half of September. The accessions were grown in $1.8 \mathrm{~m}^{2}$ plots in two replications without growth retardants. Fertilizer

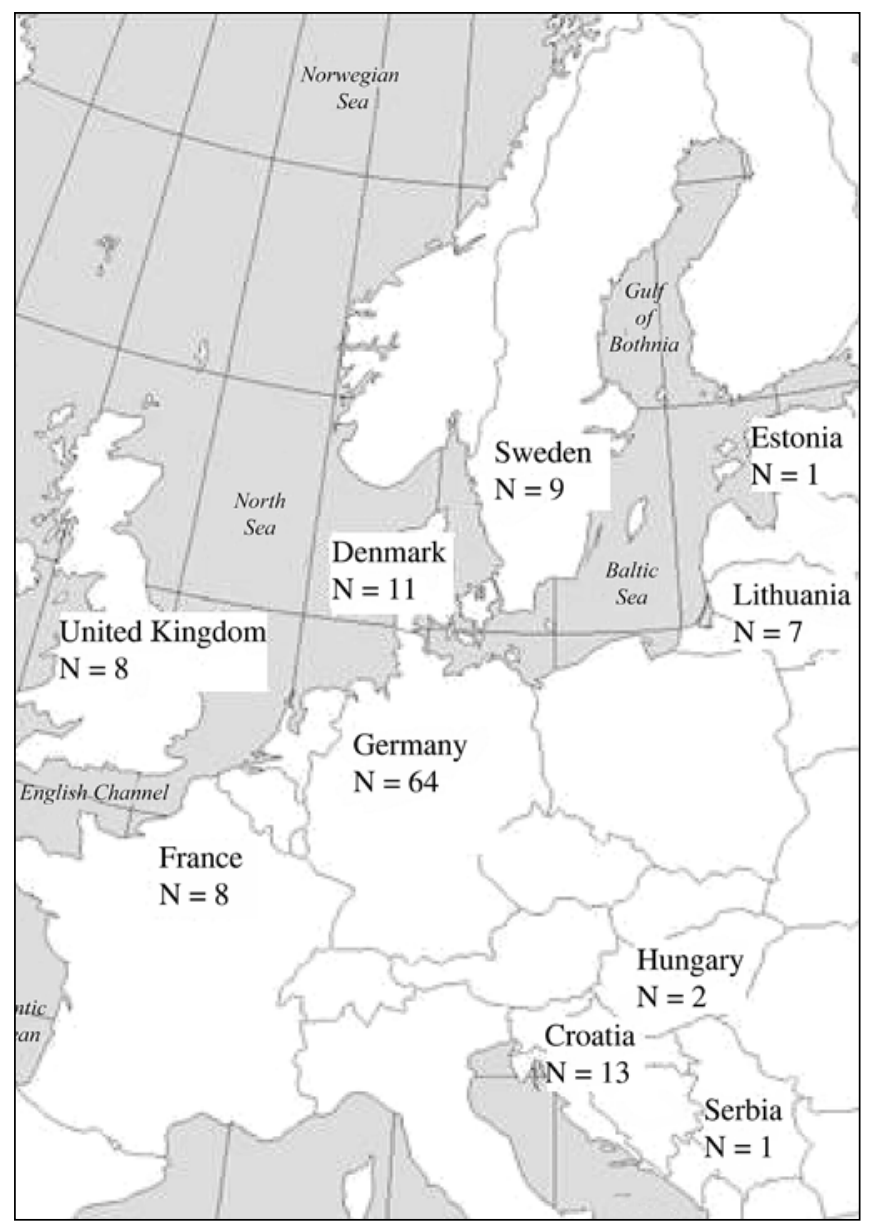

Fig. 1 Countries of origin and number of winter wheat accessions studied.

rate $\mathrm{N}_{30}-\mathrm{P}_{60}-\mathrm{K}_{60}$ was broadcast applied before sowing and additionally $\mathrm{N}_{90}$ in spring. Weeds were controlled by herbicides in autumn. Other pesticides during crop vegetation were not applied. Plant height from soil surface to tip of the ears was measured at milk stage. Grain was harvested at full seed ripe. The weather conditions during the growing season 2005/2006 were adverse due to cold winter and very dry vegetation period, whereas season 2006/2007 was favorable for the formation of maximal plant height.

\section{Evaluation of coleoptile length}

The experiment was started 6 months after harvesting to ensure higher seed germination rate. The seed fraction from 40 to $45 \mathrm{~g}$ per 1000 seeds was selected. The seed was surface sterilized in $1.0 \%$ hypochlorite solution for $30 \mathrm{~s}$ and then rinsed in sterile water. Fifteen uniform seeds per accession were spaced $1 \mathrm{~cm}$ apart and $5 \mathrm{~cm}$ from the bottom of a germination towel made from filter paper. Total height of the towel was $20 \mathrm{~cm}$. Each seed was placed on the germination towel with its embryo down. The towels were rolled loosely and fastened with a rubber band. The wrapped towels were moistened and randomly arranged vertically in closed plastic containers. The samples were placed in a growth chamber at $4^{\circ} \mathrm{C}$ for $2 \mathrm{~d}$ to interrupt dormancy. Later, the samples were incubated at the same humidity at $15^{\circ} \mathrm{C}$ for 7 days, followed by 6 days at $20^{\circ} \mathrm{C}$. The constant darkness and $100 \%$ relative humidity was maintained throughout all experiment. This procedure was replicated four and repeated two times for all accessions in both years. Coleoptile length was recorded as the distance from the 
Tab. 1 Coleoptile length and plant height of 124 European winter wheat varieties and breeding lines.

\begin{tabular}{|c|c|c|c|c|c|c|c|}
\hline Accession & Origin & $\mathrm{CL}(\mathrm{cm})$ & $\mathrm{PH}(\mathrm{cm})$ & Accession & Origin & $\mathrm{CL}(\mathrm{cm})$ & PH (cm) \\
\hline Alcazar & $\mathrm{FR}^{\mathrm{a}}$ & $4.33 \mathrm{a}^{\mathrm{b}}$ & 87 ghi $^{\text {b }}$ & Smuggler & $\mathrm{UK}^{\mathrm{a}}$ & $5.74 \mathrm{ij}^{\mathrm{b}}$ & $90 \mathrm{jk} \mathrm{l}^{\mathrm{b}}$ \\
\hline SW53114 & SE & $4.49 \mathrm{ab}$ & $83 \mathrm{f}$ & H06886-98 & $\mathrm{DE}$ & $5.76 \mathrm{ijk}$ & $96 \mathrm{qr}$ \\
\hline Marshal & UK & $4.56 \mathrm{ab}$ & $93 \mathrm{q}$ & Dekan $^{\star *}$ & $\mathrm{DE}$ & $5.76 \mathrm{ijk}$ & $81 \mathrm{~cd}$ \\
\hline Perfector & FR & $4.65 \mathrm{~b}$ & $80 \mathrm{~cd}$ & NIC993009B & $\mathrm{DE}$ & $5.80 \mathrm{ijk}$ & $90 \mathrm{jkl}$ \\
\hline Laffer & $\mathrm{DE}$ & $4.71 \mathrm{~b}$ & 89 ijk & Bc Elvira & $\mathrm{HR}$ & $5.82 \mathrm{ijk}$ & $64 \mathrm{a}$ \\
\hline Kovas & $\mathrm{LT}$ & $4.71 \mathrm{~b}$ & 86 ghi & Tuareg & $\mathrm{DE}$ & $5.87 \mathrm{jk}$ & 90 ghi \\
\hline Maverick $^{* *}$ & $\mathrm{DE}$ & $4.73 \mathrm{~b}$ & $76 \mathrm{~b}$ & Kornett ${ }^{* *}$ & $\mathrm{DE}$ & $5.88 \mathrm{jk}$ & $80 \mathrm{def}$ \\
\hline Florett & FR & $4.79 \mathrm{bc}$ & $83 \mathrm{fg}$ & Anthus & $\mathrm{DE}$ & $5.90 \mathrm{k}$ & $93 \ln$ \\
\hline Tulsa ${ }^{* * *}$ & $\mathrm{DE}$ & $4.80 \mathrm{bc}$ & $82 \mathrm{ef}$ & Heroldo ${ }^{* *}$ & $\mathrm{DE}$ & $5.90 \mathrm{k}$ & $95 \mathrm{r}$ \\
\hline Novalis ${ }^{* *}$ & $\mathrm{DE}$ & $4.81 \mathrm{bc}$ & $79 c$ & Patria & $\mathrm{HR}$ & $5.94 \mathrm{kl}$ & $72 \mathrm{ab}$ \\
\hline Certo $^{* *}$ & $\mathrm{DE}$ & $4.88 \mathrm{bcd}$ & $82 \mathrm{ef}$ & Toras** & $\mathrm{DE}$ & $5.95 \mathrm{kl}$ & $91 \mathrm{~m}$ \\
\hline Azimut & FR & $4.95 \mathrm{~cd}$ & $71 \mathrm{ab}$ & Blixen & DK & $5.95 \mathrm{kl}$ & $83 \mathrm{~g}$ \\
\hline SW Harnesk & SE & $4.98 \mathrm{~cd}$ & $84 \mathrm{~g}$ & Tauras & $\mathrm{LT}$ & $5.99 \mathrm{kl}$ & $91 \mathrm{~m}$ \\
\hline Cubus $^{* *}$ & $\mathrm{DE}$ & $5.02 \mathrm{~cd}$ & $85 \mathrm{ef}$ & Schamane & $\mathrm{DE}$ & $6.04 \mathrm{kl}$ & $85 \mathrm{~g}$ \\
\hline CEB01165 & UK & $5.07 \mathrm{cde}$ & $82 \mathrm{ef}$ & MV213-88F & $\mathrm{HU}$ & 6.051 & $95 \mathrm{q}$ \\
\hline Retro & $\mathrm{DE}$ & $5.12 \mathrm{de}$ & $96 \mathrm{qrs}$ & H27389-99 & $\mathrm{DE}$ & 6.051 & $73 \mathrm{ab}$ \\
\hline Briliant & $\mathrm{DE}$ & $5.12 \mathrm{de}$ & $90 \mathrm{kl}$ & Idol $^{*}$ & $\mathrm{DE}$ & 6.061 & $96 \mathrm{qr}$ \\
\hline Director & UK & $5.14 \mathrm{de}$ & $70 \mathrm{ab}$ & Grommit & UK & 6.081 & $88 \mathrm{fg}$ \\
\hline Privileg & $\mathrm{DE}$ & $5.15 \mathrm{de}$ & $90 \mathrm{kl}$ & Legron & $\mathrm{DK}$ & $6.13 \mathrm{~lm}$ & $75 \mathrm{~b}$ \\
\hline SW52995 & SE & $5.16 \mathrm{e}$ & $70 \mathrm{ab}$ & Bc Antea & HR & $6.13 \mathrm{~lm}$ & $65 \mathrm{a}$ \\
\hline Hattrick & $\mathrm{DE}$ & $5.17 \mathrm{e}$ & $80 \mathrm{de}$ & SW Topper* & SE & $6.18 \mathrm{~lm}$ & $90 \mathrm{jkl}$ \\
\hline SW51356 & SE & $5.20 \mathrm{e}$ & $85 \mathrm{~h}$ & Mihelica & HR & $6.19 \mathrm{~m}$ & $85 \mathrm{~g}$ \\
\hline Dorota & FR & $5.24 \mathrm{ef}$ & $86 \mathrm{fgh}$ & Olivin* & FR & $6.20 \mathrm{~m}$ & $102 \mathrm{st}$ \\
\hline Opus ${ }^{* *}$ & $\mathrm{DE}$ & $5.27 \mathrm{ef}$ & 901 & Sani & $\mathrm{EE}$ & $6.24 \mathrm{~m}$ & $110 \mathrm{uv}$ \\
\hline H07931-00 & $\mathrm{DE}$ & $5.27 \mathrm{ef}$ & $88 \mathrm{ij}$ & Sj03-1 & DK & $6.25 \mathrm{mn}$ & $83 \mathrm{~cd}$ \\
\hline Sj03-3 & DK & $5.30 \mathrm{ef}$ & $76 b c$ & Aura & $\mathrm{HR}$ & $6.27 \mathrm{mn}$ & $87 \mathrm{k}$ \\
\hline SW50867 & $\mathrm{SE}$ & $5.32 \mathrm{efg}$ & $70 \mathrm{ab}$ & Marija & $\mathrm{HR}$ & $6.28 \mathrm{mn}$ & $60 \mathrm{a}$ \\
\hline LP410.2.00 & $\mathrm{DE}$ & $5.36 \mathrm{efg}$ & $85 \mathrm{~g}$ & Sj03-4 & DK & $6.30 \mathrm{mno}$ & 80 def \\
\hline Dinosor & FR & $5.37 \mathrm{fg}$ & $85 \mathrm{~g}$ & MV106-97 & $\mathrm{HU}$ & $6.33 \mathrm{mno}$ & $93 \mathrm{qr}$ \\
\hline Sj03-5 & DK & $5.37 \mathrm{fg}$ & $87 \mathrm{k}$ & H02721-99 & $\mathrm{DE}$ & $6.41 \mathrm{o}$ & $80 \mathrm{bc}$ \\
\hline Samyl & DK & $5.38 \mathrm{~g}$ & $85 \mathrm{gh}$ & Skater* & $\mathrm{DE}$ & $6.45 \mathrm{o}$ & 90 jkl \\
\hline Agrestis & DK & $5.40 \mathrm{~g}$ & $81 \mathrm{de}$ & Tina & HR & $6.47 \mathrm{o}$ & $68 \mathrm{ab}$ \\
\hline Cardos ${ }^{* *}$ & $\mathrm{DE}$ & $5.42 \mathrm{~g}$ & $84 \mathrm{gh}$ & Nina & HR & $6.53 \mathrm{op}$ & $67 \mathrm{ab}$ \\
\hline Watson & DK & $5.43 \mathrm{~g}$ & $84 \mathrm{~g}$ & Striker*** & $\mathrm{DE}$ & $6.54 \mathrm{op}$ & $89 \mathrm{jkl}$ \\
\hline Robigus & UK & $5.43 \mathrm{~g}$ & $80 \mathrm{def}$ & Adriana & $\mathrm{HR}$ & $6.54 \mathrm{op}$ & $67 \mathrm{a}$ \\
\hline Tommi ${ }^{* *}$ & $\mathrm{DE}$ & $5.44 \mathrm{gh}$ & $80 \mathrm{de}$ & Champion & $\mathrm{DE}$ & $6.56 \mathrm{op}$ & $98 \mathrm{qrs}$ \\
\hline Skalmeje & $\mathrm{DE}$ & $5.47 \mathrm{gh}$ & 901 & Mulan & $\mathrm{DE}$ & $6.58 \mathrm{p}$ & 92 o \\
\hline H51472-00 & $\mathrm{DE}$ & $5.48 \mathrm{gh}$ & $92 \mathrm{n}$ & NIC024680A & $\mathrm{DE}$ & $6.65 \mathrm{p}$ & $105 \mathrm{t}$ \\
\hline Zebedee & UK & $5.50 \mathrm{~h}$ & $72 \mathrm{ab}$ & Prima & $\mathrm{HR}$ & $6.88 \mathrm{pq}$ & $70 \mathrm{ab}$ \\
\hline Lars & $\mathrm{DE}$ & $5.50 \mathrm{~h}$ & $90 \mathrm{kl}$ & SW Maxi* & $\mathrm{DE}$ & $6.89 \mathrm{pq}$ & $102 \mathrm{st}$ \\
\hline Zdenka & $\mathrm{HR}$ & $5.51 \mathrm{~h}$ & $80 \mathrm{de}$ & Torild & $\mathrm{DE}$ & $6.93 \mathrm{pq}$ & $90 \mathrm{jkl}$ \\
\hline Biscay ${ }^{* *}$ & $\mathrm{DE}$ & $5.52 \mathrm{~h}$ & $83 \mathrm{fgh}$ & Empire* & $\mathrm{DE}$ & $6.95 \mathrm{pqr}$ & $105 \mathrm{t}$ \\
\hline Picus & $\mathrm{DE}$ & $5.54 \mathrm{hi}$ & $88 \mathrm{fgh}$ & Zentos ${ }^{*}$ & $\mathrm{DE}$ & $6.95 \mathrm{pqr}$ & $115 \mathrm{v}$ \\
\hline Cetus & $\mathrm{DE}$ & $5.54 \mathrm{hi}$ & $73 \mathrm{~b}$ & Tiger* & $\mathrm{DE}$ & $7.11 \mathrm{qr}$ & $105 \mathrm{t}$ \\
\hline SW Tataros & $\mathrm{DE}$ & $5.54 \mathrm{hi}$ & $92 \ln$ & Alma & $\mathrm{LT}$ & $7.15 \mathrm{qr}$ & $105 \mathrm{t}$ \\
\hline Paroli ${ }^{* *}$ & $\mathrm{DE}$ & $5.56 \mathrm{hi}$ & $85 \mathrm{j}$ & Buteo* $^{*}$ & $\mathrm{DE}$ & $7.20 \mathrm{qr}$ & $105 \mathrm{tu}$ \\
\hline SW53092 & SE & $5.56 \mathrm{hi}$ & $80 \mathrm{de}$ & Türkis* & $\mathrm{DE}$ & $7.22 \mathrm{qr}$ & $95 \mathrm{pqr}$ \\
\hline Aperitif & SE & $5.57 \mathrm{hi}$ & $80 \mathrm{~cd}$ & Dromos & $\mathrm{DE}$ & $7.40 \mathrm{r}$ & $96 \mathrm{qr}$ \\
\hline Sj03-6 & DK & $5.57 \mathrm{hi}$ & $85 \mathrm{gh}$ & Zunda & $\mathrm{LT}$ & $7.54 \mathrm{r}$ & $100 \mathrm{~s}$ \\
\hline SW52747 & $\mathrm{SE}$ & $5.57 \mathrm{hi}$ & $87 \mathrm{gh}$ & Ada & LT & $7.58 \mathrm{r}$ & $110 \mathrm{uv}$ \\
\hline NIC993496B & $\mathrm{DE}$ & $5.58 \mathrm{hi}$ & $98 \mathrm{qrs}$ & Milda & $\mathrm{LT}$ & $7.64 \mathrm{rs}$ & $110 \mathrm{uv}$ \\
\hline Quebon** & $\mathrm{DE}$ & $5.58 \mathrm{hi}$ & $85 \mathrm{fgh}$ & Magister & $\mathrm{DE}$ & $7.64 \mathrm{rs}$ & $97 \mathrm{qrs}$ \\
\hline Campari** & $\mathrm{DE}$ & $5.60 \mathrm{i}$ & $85 \mathrm{~g}$ & Alitis $^{*}$ & $\mathrm{DE}$ & $8.16 \mathrm{~s}$ & $97 \mathrm{qrs}$ \\
\hline Glasgow & FR & $5.61 \mathrm{i}$ & $77 \mathrm{bc}$ & Sobi $^{*}$ & $\mathrm{DE}$ & $8.17 \mathrm{~s}$ & $90 \mathrm{jkl}$ \\
\hline Sj03-2 & DK & $5.62 \mathrm{i}$ & $77 \mathrm{bc}$ & Širvinta1 & LT & $8.18 \mathrm{~s}$ & $125 \mathrm{w}$ \\
\hline H07721-99 & $\mathrm{DE}$ & $5.64 \mathrm{i}$ & $92 n$ & Dream & $\mathrm{DE}$ & $8.42 \mathrm{st}$ & $101 \mathrm{~s}$ \\
\hline Sana & $\mathrm{HR}$ & $5.64 \mathrm{i}$ & $62 \mathrm{a}$ & Solitär* & $\mathrm{DE}$ & $8.46 \mathrm{st}$ & $104 \mathrm{st}$ \\
\hline Altos ${ }^{\star}$ & $\mathrm{DE}$ & $5.66 \mathrm{i}$ & $96 \mathrm{qr}$ & $\mathrm{Ebi}^{\star}$ & $\mathrm{DE}$ & $9.08 \mathrm{t}$ & $97 \mathrm{qrs}$ \\
\hline Actros & $\mathrm{DE}$ & $5.71 \mathrm{ij}$ & $73 \mathrm{ab}$ & Pobeda ${ }^{* * * *}$ & RS & $9.14 \mathrm{t}$ & $71 \mathrm{ab}$ \\
\hline
\end{tabular}


Tab. 1 (continued)

\begin{tabular}{lccccccc}
\hline Accession & Origin & CL $(\mathbf{c m})$ & PH $(\mathbf{c m})$ & Accession & Origin & CL (cm) & PH $(\mathbf{c m})$ \\
\hline Gatsby & UK & $5.71 \mathrm{ij}$ & $85 \mathrm{~g}$ & Pegassos & DE & $9.43 \mathrm{u}$ & $95 \mathrm{q}$ \\
Milvus $^{* *}$ & $\mathrm{DE}$ & $5.72 \mathrm{ij}$ & $82 \mathrm{ef}$ & Liberta & HR & $9.50 \mathrm{u}$ & $75 \mathrm{~b}$ \\
Hermann $^{* * *}$ & $\mathrm{DE}$ & $5.73 \mathrm{ij}$ & $90 \mathrm{jkl}$ & Flair* & DE & $9.56 \mathrm{v}$ & $98 \mathrm{qrs}$ \\
\hline
\end{tabular}

${ }^{\star}$ No Rht genes; ${ }^{* *}$ Rht-D1b; ${ }^{* * *}$ Rht-B1b [3]; ${ }^{* * * *}$ Rht8 [21]. a See Material and Methods. ${ }^{\mathrm{b}}$ Turkey multiple range test at probability level $p<$ 0.01. CL - coleoptile length; PH - plant height.

seed to where the first leaf broke through the coleoptile sheath according to Bai et al. [2].

\section{Statistical analyses}

Coleoptile length and plant height data were averaged over both years. The Tukey multiple range test with a significance level of 0.01 was used to reveal differences among accessions. Correlation analysis with a significance level $p<0.05$ and 0.01 was done to compare the relationships between coleoptile length and plant height. Least significance difference was calculated at probability level $p<0.01$.

\section{Results}

The data of the tested accessions' coleoptile length and plant height are presented in Tab. 1. Significant $(p<0.01)$ differences in coleoptile length and plant height were determined between 124 accessions from 10 European countries. The coleoptile length ranged from $4.33 \mathrm{~cm}$ in Alcazar (France, north) to $9.56 \mathrm{~cm}$ in Flair (Germany); plant height ranged from 60 $\mathrm{cm}$ in Marija (Croatia) to $125 \mathrm{~cm}$ in Širvintal (Lithuania). The coleoptile length distributed in the following way: 4.33-5.00 - 10.5\%, >5.00-6.00 - 50\%, >6.00-7.00 - 24.2\%, >7.00-8.00 $7.3 \%,>8.00-9.00-4 \%$ and $>9.00-9.56 \mathrm{~cm}-4 \%$. The Serbian variety Pobeda and Croatian variety Liberta were among the shortest $(71$ and $75 \mathrm{~cm})$ and possessed the longest coleoptiles $(9.14$ and $9.50 \mathrm{~cm})$. The tallest varieties Zentos (Germany) and Širvinta1 (Lithuania; 115 and $125 \mathrm{~cm}$ ) possessed significantly shorter coleoptiles $(6.95$ and $8.18 \mathrm{~cm})$.

The correlation analysis between coleoptile length and plant height of all 124 accessions revealed only weak correlation ( $\mathrm{r}$ $=0.382^{\star}, p<0.05$; Fig. 2 ), whereas analysis without 13 Croatian and 1 Serbian accessions increased the correlation coefficient to $r=0.613^{* *}, p<0.01$ (data not shown).

The mean coleoptile length per accession group related with the mean plant height per same group showed medium correlation $\left(r=0.536^{\star}\right)$, whereas analysis without Croatian and Serbian accessions elevated correlation coefficient to $r=0.815^{\star}$. When accessions were sorted by plant height, and means of these plant height groups were related with means of coleoptile length per group the strong correlation $\left(r=0.879^{*}\right)$ was found analyzing all accessions and very strong $\left(r=0.959^{\star}\right)$ analyzing without Croatian and Serbian accessions.

Out of the 124 accessions 18 did not possess Rht genes, 16 possessed Rht-D1b, 3 possessed Rht-B1b, 1 possessed $R h t 8$ and for the rest 86 accessions the data were not available (Tab. 2). Wheat varieties with $R h t-B 1 b, R h t-D 1 b$ or Rth 8 were significantly shorter $(87.0,84.1$ and $71.0 \mathrm{~cm})$ than varieties without Rht genes $(99.6 \mathrm{~cm})$.
Some tallest varieties with $R h t-B 1 b$ and $R h t-D 1 b$ (89 and 95 $\mathrm{cm}$ ) were similar in plant height to the shortest non-dwarf varieties $90-95 \mathrm{~cm})$. Varieties with $R h t-B 1 b$ or $R h t-D 1 b$ had significantly shorter coleoptiles $(5.69$ and $5.40 \mathrm{~cm}$ ), whereas the variety Pobeda with $R h t 8$ had longer coleoptile $(9.14 \mathrm{~cm})$ than non-dwarf varieties $(7.41 \mathrm{~cm})$. The mean coleoptile length as well as plant height of the 81 varieties for which the data were not available were 5.86 and $85.1 \mathrm{~cm}$, respectively and statistically did not differ from the accessions with Rht-B1b, Rht$D 1 b$. The coleoptile length for the accessions with $R h t-B 1 b$ and $R h t-D 1 b$ ranged from 4.73 to $6.54 \mathrm{~cm}$, whereas the accessions without $R h t$ genes showed the coleoptile length ranging from 5.66 to $9.56 \mathrm{~cm}$.

The accessions from Germany (64) dominated among the accessions tested (Tab. 3). Their mean coleoptile length was $6.18 \mathrm{~cm}$, and ranged from 4.71 to $9.56 \mathrm{~cm}$, which was the maximum coleoptile length among all accessions. The mean plant height was $90.4 \mathrm{~cm}$ and ranged from 73 to $115 \mathrm{~cm}$. Lithuanian accessions had the maximal mean coleoptile length $(6.97 \mathrm{~cm})$, whereas Hungarian $(6.63 \mathrm{~cm})$ and Croatian $(6.44 \mathrm{~cm})$ accessions did not differ significantly in the mean coleoptile length.

Also, Lithuanian accessions (mean $104 \mathrm{~cm}$ ) and one Estonian $(110 \mathrm{~cm})$ were the tallest, whereas Croatian accessions $(70.9 \mathrm{~cm})$ were the shortest. The shortest coleoptiles were noted for the accessions from France (north; $5.14 \mathrm{~cm}$ ), Sweden (5.34 $\mathrm{cm})$, United Kingdom $(5.40 \mathrm{~cm})$ and Denmark $(5.70 \mathrm{~cm})$. For these accessions plant height means ranged insignificantly from 81.0 to $83.9 \mathrm{~cm}$. However, individual accessions ranged per country significantly as follows: Sweden 70-90, United Kingdom from 70 to $93 \mathrm{~cm}$, Denmark from 75 to $87 \mathrm{~cm}$ and France from 71 to $102 \mathrm{~cm}$.

The highest range of coleoptile length was characteristic of accessions from Germany (4.71-9.56 cm) and Croatia (5.51$9.50 \mathrm{~cm})$. The highest range of plant height was specific to the accessions from Germany $(73-115 \mathrm{~cm})$ and Lithuania (89-125

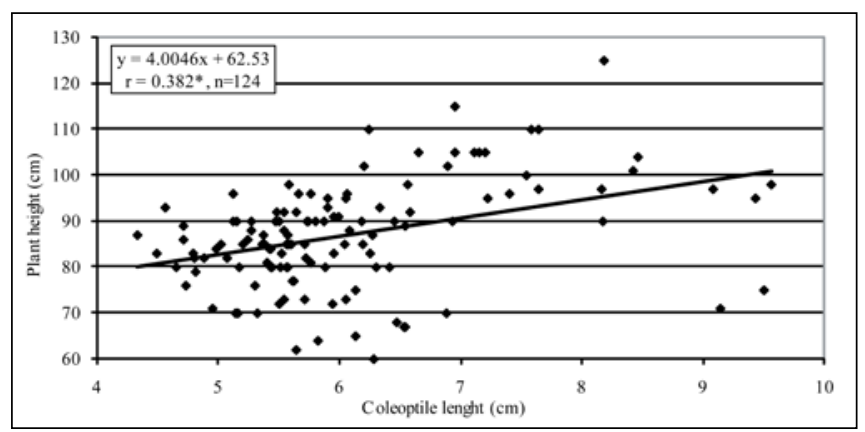

Fig. 2 Correlation of coleoptile length with plant height of winter wheat accessions studied. 
Tab. 2 Mean values of winter wheat varieties and breeding lines' coleoptile length and plant height per Rht gene group.

\begin{tabular}{|c|c|c|c|c|c|}
\hline Rht gene & Number of accessions & Mean CL $(\mathrm{cm})$ & Mean CL range $(\mathrm{cm})$ & Mean PH $(\mathrm{cm})$ & Mean $\mathrm{PH}$ range $(\mathrm{cm})$ \\
\hline No Rht gene & 18 & 7.41 & $5.66-9.56$ & 99.6 & $90-115$ \\
\hline$R h t-D 1 b$ & 16 & 5.40 & $4.73-5.95$ & 84.1 & $76-95$ \\
\hline Rht8 & 1 & 9.14 & 9.14 & 71.0 & 71 \\
\hline Not determined & 86 & 5.86 & $4.33-9.50$ & 85.1 & $60-125$ \\
\hline $\mathrm{LSD}_{01}^{*}$ & & 0.64 & & 9.1 & \\
\hline
\end{tabular}

* Least significant difference at probability level $p<0.01$. CL - coleoptile length; PH - plant height.

$\mathrm{cm})$. The mean height $(80.6 \mathrm{~cm})$ of all accessions suggests that medium dwarfs dominate in Europe.

\section{Discussion}

Distribution of accessions' coleoptile length was similar to that found in many other experiments [2,18,22,23]. Most of the accessions differed significantly in coleoptile length. Very short $(4.0-5.0 \mathrm{~cm})$ coleoptiles were characteristic of $10.5 \%$ and some longer $(>5.0-6.0 \mathrm{~cm})$ of $50 \%$ of accessions. These findings evidence that deep sowing is not appropriate for most of the varieties. The data on the European varieties' coleoptile length are very limited suggesting that deep sowing is not used and experiments are in progress.

Different methods are employed for coleoptile length measurement. They differ in germinating medium (paper towels or soil substrates) and temperature regime. Coleoptile length determined by a paper towel method should be lower than that obtained by soil substrates method [24]. The temperature regime used in our experiment did not warrant the maximal coleoptile length. However, the majority of investigations show that wheat genotypes retain their ranking across temperatures and lines producing long coleoptiles at higher temperatures should produce longer ones at cooler temperatures [22]. On the other hand, some quantitative trait loci (QTLs) influencing coleoptile length can perform better at higher than at lower temperatures [25]. Also, it was determined that seed source for coleoptile measurements had little effect on coleoptile length [26]. Such relationship allows more flexible use of the evaluation methods. Among the 124 accessions tested only $8 \%$ possessed coleoptiles longer than $8 \mathrm{~cm}$ and none of them exceeded $10 \mathrm{~cm}$. Such a low frequency of accessions with long coleoptiles shows that high accuracy could hardly improve experimental data. The constraint is that hundreds if not thousands of accessions should be screened during the initial screening stages to find the several ones possessing long coleoptiles in combination with desirable traits for each specific area. On the other hand, high correlation between sites and years [20,26] could help screening of many accessions in certain institutions using seed samples received from other geographical regions or previous yield years, which saves time and inputs necessary for reproduction of these accessions at the same institution.

Close to normal distribution of coleoptile length as well as plant height shows genetic variability based on combinations of mono and polygenes [27]. The genetic mechanisms regulating coleoptile length are not comprehensively studied. One of the constraints is masking effect of $R h t$ genes. The tested varieties without $R h t$ genes possessed a coleoptile length ranging from 5.66 to $9.56 \mathrm{~cm}$ and a plant height from 90 to 115 $\mathrm{cm}$. Denying the presence of unknown Rht genes it is possible to state that coleoptile length and plant height of these

Tab. 3 Mean values of winter wheat varieties and breeding lines' coleoptile length and plant height per country of origin.

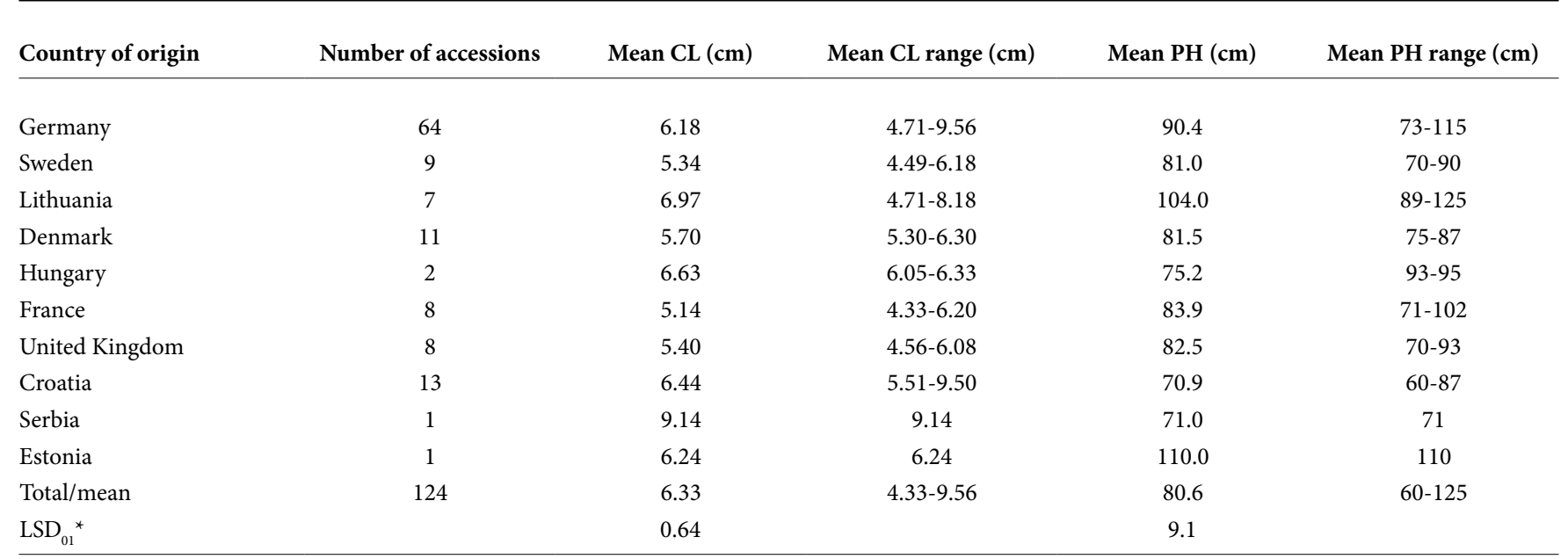

${ }^{\star}$ Least significant difference at probability level $p<0.01$. CL - coleoptile length; PH - plant height. 
accessions are completely under polygenic control. Recent research showed many QTLs regulating coleoptile length with major and minor effects. QTLs were identified on a range of chromosomes 1B, 2B, 2D, 3D, 4A, 4B, 4DL, 4DS, 5AS, 5B, 5D, $6 \mathrm{~A}, 6 \mathrm{~B}[17,20,25,27,28]$. At the same time, some of these QTLs showed pleiotropic effects on plant height, but others did not. QTL's, increasing coleoptile length but not associated with plant height, may be useful for improving long coleoptiles with decreased plant height. Plant height of accessions without $R h t$ genes did not correlate $(r=-0.02)$ with coleoptile length. It indicates that these accessions possess various plant height and coleoptile length regulating QTLs. For example, the tallest varieties Ada, Zentos, Širvintal $(110-125 \mathrm{~cm})$ did not possess the longest coleoptiles $(6.95-8.18 \mathrm{~cm})$, whereas varieties Ebi, Flair, Pegassos possessing the longest coleoptiles $(9.08-9.56 \mathrm{~cm})$ had about $20 \%$ shorter plant height $(95-98 \mathrm{~cm})$. A weak positive $(\mathrm{r}$ $=0.496$ ) correlation was obtained for the accessions with Rht$D 1 b$. It shows that these varieties also possess a range of QTLs for plant height and coleoptile length.

Positive correlations between plant height and coleoptile length were determined in our study, but the relation level was highly dependent on accession selection for analysis. These results agree with various studies on wheat coleoptiles [17,20,22]. Winter wheat varieties from Central European countries exerted the main negative effect on this correlation. Pobeda, the only variety out of 14 Central European varieties was investigated for Rht genes and possessed Rht8 [21]. No evidence on the rest of the varieties was found. However, considering $R h t$ gene array and high frequency of Rht8 in the winter wheat pool from Central Europe [5,21] and assuming the ratio of coleoptile length to plant height of accessions possessing various $R h t[2,18]$, some of these varieties might possess $R h t 8$. The genes Rht-B1b and Rht-D1b influence prostrate growth habit and narrow seedling leaves, whereas accessions possessing gene Rht8 develop more erect and wider seedling leaves [18]. The Croatian varieties Zdenka and Aura exhibited prostrate seedling growth habit as well as varieties possessing $R h t$ $B 1 b$ and $R h t-D 1 b$ (data not shown). Coleoptiles of the varieties Zdenka and Aura were similar in length $(5.51$ and $6.27 \mathrm{~cm})$ like the varieties possessing $R h t-B 1 b$ and $R h t-D 1 b$ (4.73-6.54 $\mathrm{cm})$. As a result, these varieties should possess $R h t-B 1 b$ or $R h t$ $D 1 b$ alone but not in combination with $R h t 8$. The coleoptile length and plant height did not correlate $(r=-0.183)$ when accessions were grouped by countries. Accessions from Sweden, Denmark, United Kingdom and France possessed the shortest mean length of coleoptiles $(5.14-5.70 \mathrm{~cm})$. These countries are characterized by maximal winter wheat yields in Europe. Therefore, growing of short cultivars considerably determines high yield. On the other hand, the accessions from the countries with a lower productivity possessed longer mean coleoptiles $(6.18-6.97 \mathrm{~cm})$ and plant height $(75.2-110 \mathrm{~cm})$. Only Croatian and Serbian accessions diverged in plant height coleoptile length due to Rht8 in some accessions.

Various combinations of coleoptile length to plant height show that selection of accessions possessing long coleoptiles is complicated. However, the trends are more promising for accessions other than Central Europe varieties. Firstly, it is obvious that $R h t-B 1 b$ and $R h t-D 1 b$ were associated with reduced coleoptile length (Tab. 2). Secondly, some varieties (Skater, SW Topper, Sobi, Pegassos, and Türkis) without $R h t$ genes had similar plant height $(90-95$, mean $92 \mathrm{~cm})$ to that of the varieties (Striker, Herman, Opus, Toras, Heroldo) with Rht-B1b or $R h t-D 1 b(89-95$, mean $91 \mathrm{~cm})$. The coleoptile length of the first group of varieties ranged from 6.18 to $9.43 \mathrm{~cm}$, with the mean $7.49 \mathrm{~cm}$, whereas coleoptile length of the second group of varieties ranged from 5.27 to 6.54 , with mean $5.78 \mathrm{~cm}$. The coinciding plant height, but not coleoptile length data of varieties possessing different dwarfing factors suggests a possibility to develop new varieties without $R h t$ genes with acceptable height in combination with long coleoptiles and other desirable agronomic traits. According to BSA $[29,30]$ the above mentioned varieties without $R h t$ genes were cultivated in Germany during their intensive use period and the area under them was twice as high as that of the above mentioned varieties possessing Rht-B1b and Rht-D1b. This suggests that plant height control without $R h t$ genes was successfully fulfilled in breeding and agricultural praxis. For instance, previous research on Japanese wheat showed that accessions with Rht-B1b and Rht-D1b did not possess satisfactory plant height without minor dwarfing genes [31]. Coleoptile length depends on polygenic inheritance, many QTLs were determined [17,20,25,27,28], but much fewer QTLs exerted major effect. Such relation shows relatively straightforward wheat breeding for long coleoptile exploiting European wheat pool as the few major QTLs ensure sufficiently high heritability [22] and possibility to use marker assisted selection [28]. Involvement of exotic germplasm could facilitate development of new European wheat varieties with very long coleoptiles and accelerate breeding for this trait. The problem of deep sowing is not particularly relevant in Europe at the moment. The transfer of a new trait relies on the advantages of the newly developed varieties with new traits over existing ones. Therefore, the most promising option for the development of varieties with improved coleoptile length and desirable plant height lies in the choice of European winter wheat germplasm.

\section{References}

1. Schillinger WF, Donaldson E, Allan RE, Jones SS. Winter wheat seedling emergence from deep sowing depths. Agron J. 1998;90(5):582-586. doi:10.2134/agronj1998.000 21962009000050002x.

2. Bai G, Das MK, Carver BF, Xu X, Krenzer EG. Covariation for microsatellite marker alleles associated with $R$ ht 8 and coleoptile length in winter wheat. Crop Sci. 2004;44:11871194. doi:10.2135/cropsci2004.1187.

3. Knopf C, Becker H, Ebmeyer E, Korzun V. Occurrence of three dwarfing Rht genes in German winter wheat varieties. Cereal Res Commun. 2008;36(4):553-560. doi:10.1556/ CRC.36.2008.4.4.

4. Miedaner T, Voss H. Effect of dwarfing Rht genes on Fusarium head blight resistance in two sets of near-isogenic lines of wheat and check cultivars. Crop Sci. 2008;48:21152122. doi:10.2135/cropsci2008.02.0107.

5. Worland AJ, Sayers EJ, Korzun V. Allelic variation at the dwarfing gene Rht8 locus and its significance in international breeding programmes. Euphytica. 2001;119(12):157-161. doi:10.1023/A:1017582122775.

6. Feizienė D, Feiza V, Lazauskas S, Kadžienė G, Šimanskaitė G, Deveikytè I. The influence of soil management on soil properties and yield of crop rotation. Žemdirbystè. 2007;94:129-145.

7. Lavalle C, Micale F, Houston TD, Camia A, Hiederer R, Lazar C, et al. Climate change in Europe. 3. Impact on agriculture and forestry. A review. Agron Sustain Dev. 2009;29(3):14. doi:10.1051/agro/2008068. 
8. European Conservation Agriculture Federation [Internet]. 2009 [cited 2009 Dec 29]; Available from: http:// www.ecaf.org

9. Ferranti L, Viterbo P. The European summer of 2003: sensitivity to soil water initial conditions. J Climate. 2006;19:3659-3680. doi:10.1175/JCLI3810.1.

10. Meehl GA, Tebaldi C. More intense, more frequent, and longer lasting heat waves in the 21 st century. Science. 2004;305(5686):994-997. doi:10.1126/science.1098704.

11. Rebetzke GJ, Bruce SE, Kirkegaard JA. Longer coleoptiles improve emergence through crop residues to increase seedling number and biomass in wheat (Triticum aestivum L.). Plant Soil. 2005;272(1-2):87-100. doi:10.1007/ s11104-004-4040-8.

12. Radford BJ, Strong WM, Wilderminth GB. Effects of urea and flutriafol on germination, coleptile length and establishment of wheat and barley. Aust J Exp Agric. 1989;29(4):551-557. doi:10.1071/EA9890551.

13. Pinthus MJ, Abraham M. Effects of light, temperature, gibberellin $\left(\mathrm{GA}_{3}\right)$ and their interaction on coleoptile and leaf elongation of tall, semi-dwarf and dwarf wheat. Plant Growth Regul. 1996;18(3):239-247. doi:10.1007/ BF00024388.

14. Cornish PS, Hindmarsh S. Seed size influences the coleoptile length of wheat. Aust J Exp Agric. 1988;28(4):521-523. doi:10.1071/EA9880521.

15. Brown PR, Singleton GR, Tann CR, Mock I. Increasing sowing depth to reduce mouse damage to winter crops. Crop Prot. 2003;22(4):653-660. doi:10.1016/ S0261-2194(03)00006-1.

16. Condon AG, Richards RA, Rebetzke GJ, Farquhar GD. Breeding for high water-use efficiency. J Exp Bot. 2004;55(407):2447-2460. doi:10.1093/jxb/erh277.

17. Spielmeyer W, Abromeit J, Joaquim P, Azanza F, Bonnett D, Ellis ME, et al. A QTL on chromosome 6A in bread wheat (Triticum aestivum) is associated with longer coleoptiles, greater seedling vigour and final plant height. Theor Appl Genet. 2007;115(1):59-66. doi:10.1007/s00122-007-0540-2.

18. Addisu M, Snape JW, Simmonds JR, Gooding MJ. Reduced height $(R h t)$ and photoperiod insensitivity $(P p d)$ allele associations with establishment and early growth of wheat in contrasting production systems. Euphytica. 2009;166(2):249-267. doi:10.1007/s10681-008-9838-7.

19. Bertholdsson NO. Early vigour and allelopathy - two useful traits for enhanced barley and wheat competitiveness against weeds. Weed Res. 2005;45(2):94-102. doi:10.1111/j.1365-3180.2004.00442.x.
20. Yu J, Bai G. Mapping quantitative trait loci for long coleoptile in Chinese wheat landrace Wangshuibai. Crop Sci. 2010;50:43-50. doi:10.2135/cropsci2009.02.0065.

21. Ganeva G, Korzun V, Landjeva S, Tsenov N, Atanasova M. Identification, distribution and effects on agronomic traits of the semi-dwarfing Rht alleles in Bulgarian common wheat cultivars. Euphytica. 2005;145(3):305-315. doi:10.1007/s10681-005-1742-9.

22. Rebetzke GJ, Richards RA, Fischer VM, Mickelson BJ. Breeding long coleoptile, reduced height wheats. Euphytica. 1999;106(2):159-168. doi:10.1023/A:1003518920119.

23. Tang N, Jiang Y, He B, Hu Y. The effects of dwarfing genes (Rht-B1b, Rht-D1b, and Rht8) with different sensitivity to $\mathrm{GA}_{3}$ on the coleoptile length and plant height of wheat. Agr Sci China. 2009;8(9):1028-1038.

24. Takahashi H, Abraham M, Sakurai K, Watanabe A, Akagi $\mathrm{H}$, Sato K, et al. QTLs in barley controlling seedling elongation of deep-sown seeds. Euphytica. 2008;164(3):761768. doi:10.1007/s10681-008-9720-7.

25. Rebetzke GJ, Appels R, Morrison AD, Richards RA, McDonald G, Ellis MH, et al. Quantitative trait loci on chromosome $4 \mathrm{~B}$ for coleoptile length and early vigour in wheat (Triticum aestivum L.). Aust J Agric Res. 2001;52(12):12211234. doi:10.1071/AR01042.

26. Hakizimana F, Haley SD, Turnipseed EB. Repeatability and genotype $\times$ environment interaction of coleoptile length measurements in winter wheat. Crop Sci. 2000;40:12331237. doi:10.2135/cropsci2000.4051233x.

27. Rebetzke GJ, Ellis MH, Bonnett DG, Richards RA. Molecular mapping of genes for coleoptile growth in bread wheat (Triticum aestivum L.). Theor Appl Genet. 2007;114(7):1173-1183. doi:10.1007/s00122-007-0509-1.

28. Wang J, Chapman SC, Bonnett DG, Rebetzke GJ. Simultaneous selection of major and minor genes: use of QTL to increase selection efficiency of coleoptile length of wheat (Triticum aestivum L.). Theor Appl Genet. 2009;119(1):6574. doi:10.1007/s00122-009-1017-2.

29. Bundessortenamt - BSA [Internet]. Beschreibende Sortenliste. 2005 [cited 2010 Jan 6]; Available from: http://www. bundessortenamt.de/internet30/index.php?id=23

30. Bundessortenamt - BSA [Internet]. Beschreibende Sortenliste. 2009 [cited 2010 Jan 6]; Available from: http://www. bundessortenamt.de/internet30/index.php?id=23

31. Yamada T. Classification of GA response, $R h t$ genes and culm length in Japanese varieties and landraces of wheat. Euphytica. 1990;50(3):221-239. doi:10.1007/BF00023648. 